\title{
PROXIMATE AND MINERAL COMPOSITION OF SELECTED SOYBEAN GENOTYPES IN NIGERIA
}

\author{
Dickson Junior NWOSU $^{1 *}$, Mayowa Raphael OLUBIYI ${ }^{1}$, Sunday Ezekiel ALADELE ${ }^{1}$, \\ Benson APUYOR ${ }^{2}$, Anthony Ugochukwu OKERE ${ }^{1}$, Adetunji Ismael LAWAL ${ }^{3}$, \\ Gloria AFOLAYAN ${ }^{1}$, Abisoye Oyepero OJO ${ }^{1}$, Christopher NWADIKE ${ }^{4}$, \\ Myung-Chul LEE ${ }^{5}$, Edna Chidinma NWOSU6
}

\author{
${ }^{1}$ National Centre for Genetic Resources and Biotechnology (NACGRAB), P.M.B. 5382, \\ Moor Plantation, Ibadan - Nigeria \\ ${ }^{2}$ Department of Plant Breeding and Seed Science, University of Agriculture Makurdi - Nigeria, \\ National Cereals Research Institute (NCRI), Badeggi - Nigeria \\ ${ }^{3}$ Department of Food Technology, Faculty of Technology, University of Ibadan, Oyo State - Nigeria \\ ${ }^{4}$ Department of Agricultural Technology, Forestry Research Institute of Nigeria, Federal College of \\ forestry, Jos P.M.B 2019. Jos-Plateau State - Nigeria \\ ${ }^{5}$ National Agrobiodiversity Center, Rural Development Administration, Republic of Korea \\ ${ }^{6}$ Star Kids Christian Life Academy, Port Harcourt - Nigeria \\ *Corresponding author. E-mail: dicksonnwosu@gmail.com
}

Abstract: An experiment was conducted at the Central Services Laboratory of the National Cereals Research Institute, Badeggi, Nigeria to evaluate proximate and mineral composition of eight soybean accessions (NG/MR/11/11/060, NG/SA/07/100, NG/SA/JAN/09/48, NGB00111, NGB00113, NGB00116, NGB01318) conserved in the National Genebank at National Centre for Genetic Resources and Biotechnology [NACGRAB), Ibadan, Nigeria and twelve varieties (TGX1019-2EB, TGX1019-2EN, TGX1440-1E, TGX1448-2E, TGX1485-1D, TGX1835-10E, TGX1904-6F, TGX1951-3F, TGX198762F, TGX1989-19F, TGX923-2E, TGX1987-10F) developed at National Cereals Research (NCRI) in collaboration with International Institute for Tropical Agriculture (IITA) and the result showed wide significant variations in the proximate and mineral contents. TGX1987-62F recorded the highest dry matter content of $98.34 \%$ while TGX 923-2E gave the highest moisture content $(6.12 \%)$. Highest values for Crude ash $(5.02 \%)$ and crude fibre $(6.12 \%)$ were recorded for TGX1951-3F. NGB00116 had the significantly highest protein content of $41.92 \%$ and an appreciable oil content of $27.65 \%$. Protein content was also high for TGX1987-10F (41.33\%) and NG/MR/11/11/060 (41.31\%). TGX1989-19F had the highest oil content of 30.45\% and energy value (496.37 Kcal/g). NGB00113 had the highest carbohydrate content of $52.74 \% . \mathrm{K} . \mathrm{Na}, \mathrm{Ca}, \mathrm{Mg}$ and $\mathrm{P}$ were highest in NG/SA/JAN/09/48 (1.99\%), NGB00116 (0.57\%), TGX1485-1D (1.60\%) TGX1951-3F (0.84\%) and NGB00113 $(0.85 \%)$ respectively. The study provides valuable information on soybean genotypes with very high protein and oil content for recommendation to farmers and other end users and for breeders to select and utilize in soybean quality improvement programmes.

Keywords: accessions, oil content, protein content, proximate, soybean.

\section{Introduction}

Soybean (Glycine max (L.) Merr.) is a member of Leguminosae family, believed to have originated in Northeastern China and distributed in Asia, USA, Brazil, Argentina and other parts of the world. This crop is aptly called as "Miracle crop" of the $20^{\text {th }}$ century due to its multiple uses. Soybean with an average protein content of $40 \%$ and oil content of $20 \%$ has the highest protein of all crops for food and feed [SHARMA \& al. 2013; HOSSAIN \& KOMATSU, 2014], including those of cowpea and common bean [NWADIKE \& al. 2018], 
and second only to groundnut in terms of oil content among food legumes. Compared to other protein rich foods such as meat, fish, and eggs, it is by far the cheapest. Soybean seeds have been described as "protein hope" of the future [SATHE \& al. 2009] and meat that grows on plant [LEHNER \& GAWRISCH, 2000] owing to its high nutritive value. Soybean seeds besides being rich in proteins, contain unsaturated, cholesterol free fatty acids, minerals and vitamins $\mathrm{A}, \mathrm{B}, \mathrm{C}$ and $\mathrm{D}$ which meet the nutritional needs of humans and other animals [MALEK \& al. 2014; GHOSH \& al. 2014], and contain numerous antioxidants beneficial to human health, as they significantly reduce the risk of many diseases [KUMAR \& al. 2014].

Nigeria is the largest producer in Africa. Though, soybean is grown in many states of Nigeria, the Northern and Southern guinea savanna regions record the highest soybean production. Production mainly in the southern Guinea savanna zone comprising Benue, Kaduna, Oyo, Ondo, Adamawa, Taraba and Plateau with Benue as the highest [SMITH \& al. 1995]. According to ODELEYE \& al. (2007), there is a wide margin between what is needed and what is currently produced.

Due to its great potentials in Nigeria for oil production and relatively cheap protein source for the vast resource poor populace, evaluation of collections released varieties and accessions is necessary to identify their individual nutritional composition. Information on the protein content of soybean varieties released over the years in Nigeria is non-existent at worst and at best rare to come by in literature. This may be due to the general assumption that soybean is rich in protein and oil. Thus most of the varieties released in Nigeria are based on seed yield, early maturity, low shattering and resistance to disease especially rust. Similarly, accessions held in the National Genebank have not been previously evaluated for nutritional content. Therefore, this pioneer attempt to unravel the proximate and mineral compositions of some released varieties as well as accessions will give depth knowledge to the wealth of nutrient in each studied genotype. This will also provide very useful information for breeders seeking to improve the nutritional quality of this crop while equipping farmers and the populace with information on the specific varieties to plant and consume for specific nutritional needs.

\section{Materials and methods}

\section{Genotypes used for the study and evaluated parameters}

Twenty (20) soybean genotypes (Table 1) comprising 11 varieties released in Nigeria and 9 accessions collected from different parts of Nigeria and held in trust of the National Genebank at National Centre for Genetic Resources and Biotechnology (NACRAB), Ibadan, Nigeria were evaluated for proximate and macro mineral nutrient contents. Percentage compositions in dry matter, moisture, ash, crude fat/oil, crude protein, crude fibre, carbohydrate and energy value (Kcal/g) were evaluated. Potassium (K), sodium $(\mathrm{Na})$, calcium $(\mathrm{Ca})$, magnesium $(\mathrm{Mg})$ and phosphorus $(\mathrm{P})$ contents of these genotypes were also evaluated. The experiment was conducted at the General Laboratory of National Cereals Research Institute, Badeggi, Nigeria.

\section{Proximate Composition}

Seed bean nitrogen $(\mathrm{N})$ was determined by the thermal conductivity procedure that included the combustion of the sample to $40{ }^{\circ} \mathrm{C}$ [SADZAWKA \& al. 2007]. The N content of the seed was multiplied by 6.25 to obtain the protein content [GUZMÁN-MALDONADO $\&$ al. 2000]. Moisture content was determination using the air oven method. Crucibles were washed and dried in an oven. They were allowed to cool in the desiccator and weight was 
Dickson Junior NWOSU \& al.

noted. A known weight of samples were then transferred into the crucibles and dried at a temperature between $103-105^{\circ} \mathrm{C}$. The dry samples were cooled in a desiccator and the weight noted. They were later returned to the oven and the process continued until constant weights were obtained. Moisture content was calculated using the formula:

$$
\% \text { moisture content }=\frac{\text { weight loss } \times 100}{\text { weight of smaple }}
$$

Ash content was determined by weighing of finely ground sample into clean, dried previously weighed crucible with lid (W1). The sample was ignited over a low flame to char the organic matter with lid removed. The crucible was then placed in muffle furnace at 600 ${ }^{\circ} \mathrm{C}$ for $6 \mathrm{~h}$ until it ashed completely. It was then transferred directly to desiccators, cooled and weighed immediately (W2).

$$
\% \text { Ash content }=\frac{\text { weight loss } \times 100}{\text { weight of smaple }}
$$

Crude fat was determined using Soxhlet apparatus. A known weight of sample was weighed into a weighed filter paper and folded neatly. This was put inside pre-weighed thimble (W1). The thimble with the sample (W2) was inserted into the Soxhlets apparatus and extraction under reflux was carried out with petroleum ether $\left[40{ }^{\circ} \mathrm{C}-60{ }^{\circ} \mathrm{C}\right.$ boiling range) for $6 \mathrm{~h}$. At the end of extraction, the thimble was dried in the oven for about 30 minutes at $100{ }^{\circ} \mathrm{C}$ to evaporate off the solvent and the thimble was cooled in a desiccator and later weighed (W3). The fat extracted from a given quantity of sample was then calculated:

$$
\% \text { Fat }=\frac{\text { loss in weight of sample } \times 100}{\text { original weight of smaple }}
$$

Crude fibre was determined by taking the fat free extract obtained after determining Ether Extract and weight part of it. This is then serially heated with dilute acid and dilute alkali to hydrolyze away the digestible portion. The residue is dried and weighed. This weight, minus the weight of ash represents the fibre content. The percentage carbohydrate content of seeds was determined by summing up the percentages of moisture, ash, crude protein, fat (ether extract) and subtracting from $100 \% \mathrm{CHO}=100-($ Sum of the percentages of moisture, ash, fat, protein and crude fibre). The difference in value was taken as the percentage total carbohydrate content of seed [A.O.A.C., 2006; AMEH, 2007].

\section{Mineral composition analysis}

Twenty (20) accessions of soybean genotypes were analyzed for $\mathrm{Ca}, \mathrm{Fe}, \mathrm{B}, \mathrm{Zn}, \mathrm{K}$, $\mathrm{Mg}, \mathrm{Mn}$ and $\mathrm{P}$ by flame atomic absorption spectrometry (Perkin-Elmer spectrophotometer, model 1100B, Phoenix, Arizona, USA), [SADZAWKA \& al. 2007]. Bean seed samples were ground to a fine powder to ensure homogeneity before analysis of macro and micronutrients. The samples were concentrated by evaporating $100 \mathrm{ml}$ of sample to about $20 \mathrm{ml}$. They were thereafter aspirated through the nebulizer into the air-acetylene flame where atomization took place. Using a source lamp for each element, the amount of energy absorbed in the flame is proportional to the concentration of the element in the sample over a limited concentration range. 


\section{Statistical Analysis}

All data were subjected to an ANOVA. The least significant difference (LSD) was used to compare the means of the genotypes using the STAR (2014) statistical software. Significantly different means were separated using SNK at $\mathrm{P} \leq 0.05$ probability level.

Table 1. List and sources of plant materials used in the experiment

\begin{tabular}{|c|c|c|c|}
\hline $\mathbf{S} / \mathbf{N}$ & Accessions & Source & Status \\
\hline 1 & NG/AA/SEP/09/166 & NACGRAB, Ibadan & Farmer's cultivar conserved in the genebank \\
\hline 2 & NG/MR/11/11/060 & “ & “ \\
\hline 3 & NG/SA/07/100 & “ & “ \\
\hline 4 & NG/SA/JAN/09/48 & “ & “ \\
\hline 5 & NGB 00111 & “ & “ \\
\hline 6 & NGB 00113 & “ & “ \\
\hline 7 & NGB 00116 & “ & “ \\
\hline 8 & NGB 01318 & “ & " \\
\hline 9 & TGX 1019-2EB & IITA, Ibadan & Improved registered variety \\
\hline 10 & TGX 1019-2EN & “ & “ \\
\hline 11 & TGX 1440-1E & “" & “" \\
\hline 12 & TGX 1448-2E & “" & “" \\
\hline 13 & TGX 1485-1D & “" & “ \\
\hline 14 & TGX 1835-10E & “" & “ \\
\hline 15 & TGX 1904-6F & “" & “ \\
\hline 16 & TGX 1951-3F & “ & “ \\
\hline 17 & TGX 1987-62F & “ & “ \\
\hline 18 & TGX 1989-19F & “ & “ \\
\hline 19 & TGX 923-2E & " & “ \\
\hline 20 & TGX1987-10F & “ & “ \\
\hline
\end{tabular}

\section{Results}

Results of the proximate and mineral compositions of twenty soybean genotypes (Table 2) showed significant differences for all the evaluated parameters. Total dry matter (\%) value of $98.34 \%$ recorded for TGX1987-62F was significantly highest, followed by $97.27 \%$ for TGX1019-2EN. TGX923-2E had the least dry matter content of $93.48 \%$. Moisture content varied significantly among the genotypes with TGX923-2E (6.12\%) and TGX1989-19F (5.12\%) having the highest moisture contents while, least moisture content of $1.88 \%$ was observed for TGX1987-62F. NGB00116 recorded the highest ash content of $5.36 \%$, while BG/SA/JAN/09/48 had the lowest (3.34\%).

Crude fat/oil content varied significantly with the highest value of $30.45 \%$ recorded for TGX1989-19F, followed by $28.44 \%$ and $28.11 \%$ recorded in NG/MR/11/11/060 and TGX1904-3F respectively. The least value of $21.12 \%$ recorded for NG/SA/JAN/09/48. Protein content was significantly highest at $41.92 \%$ for NG00116 followed by $41.33 \%$, $41.31 \%$ and $40.32 \%$ in TGX1987-10F, NG/AA/SEP/09/166 and TGX1835-10E respectively. NG00113 (12.96\%) had the lowest recorded crude protein.

Crude fibre (\%) was observed to be highest in TGX1951-3F recording $6.12 \%$ followed by TGX1440-1E (6.09\%), but the least value for this parameter observed in TGX923-2E was $3.75 \%$. NGB00113 (52.74\%) recorded significantly highest carbohydrate value followed by TGX1019-2EN (46.64\%). The least value for carbohydrate $(15.83 \%)$ was recorded for NGB00116. Energy value (Kcal/g) was significantly highest for TGX1989-19F 
Dickson Junior NWOSU \& al.

at $496.37 \mathrm{Kcal} / \mathrm{g}$. The genotype with significantly lowest energy value of $459.97 \mathrm{Kcal} / \mathrm{g}$ was TGX1440-1E.

Mineral composition results (Table 3) showed that NG/SA/JAN/09/48 (1.99\%) and TGX923-2E (1.09\%) had the significantly highest and lowest potassium (K\%) content respectively among the genotypes used in this study. Sodium $(\mathrm{Na} \%)$ composition was significantly highest in NGB00116 (0.57\%) and lowest in NG/MR/11/11/060 (0.10\%). Similarly, NG/SA/JAN/09/48 (1.60\%) and TGX 1485-1D (1.60\%) had significantly highest calcium compositions. This value was not significantly different from $1.57 \%$ and $1.56 \%$ recorded for TGX1987-62F and NGB00111 respectively (Table 3).

Magnesium $(\mathrm{Mg} \%)$ composition varied from $0.84 \%$ significantly highest in TGX1951-3F to 0.15\% lowest in TGX 1019-2EB and TGX1987-62F (Table 3). NGB00113 $(0.85 \%)$ was significantly highest in phosphorus (P\%) followed by $0.78 \%$ in TGX 1019-2EN. TGX 1019-2EB (0.26\%) and TGX1987-10F (0.27\%) had the least phosphorus contents.

Table 3. Mineral composition of 20 soybean genotypes in Nigeria

\begin{tabular}{|c|c|c|c|c|c|}
\hline Genotype & $\mathbf{K}(\%)$ & $\mathrm{Na}(\%)$ & $\mathrm{Ca}(\%)$ & $\operatorname{Mg}(\%)$ & $\mathbf{P}(\%)$ \\
\hline NG/AA/SEP/09/166 & 1.76 & 0.47 & 0.99 & 0.47 & 0.62 \\
\hline NG/MR/11/11/060 & 1.76 & 0.10 & 0.58 & 0.81 & 0.59 \\
\hline NG/SA/07/100 & 1.36 & 0.23 & 1.48 & 0.58 & 0.44 \\
\hline NG/SA/JAN/09/48 & 1.99 & 0.53 & 1.60 & 0.39 & 0.46 \\
\hline NGB 00111 & 1.72 & 0.20 & 1.56 & 0.82 & 0.45 \\
\hline NGB 00113 & 1.45 & 0.26 & 0.86 & 0.45 & 0.85 \\
\hline NGB 00116 & 1.72 & 0.57 & 1.24 & 0.45 & 0.72 \\
\hline NGB 01318 & 1.58 & 0.51 & 1.06 & 0.54 & 0.34 \\
\hline TGX 1019-2EB & 1.68 & 0.46 & 1.09 & 0.15 & 0.26 \\
\hline TGX 1019-2EN & 1.39 & 0.44 & 0.94 & 0.21 & 0.78 \\
\hline TGX 1440-1E & 1.67 & 0.24 & 0.76 & 0.65 & 0.46 \\
\hline TGX 1448-2E & 1.84 & 0.54 & 0.96 & 0.15 & 0.55 \\
\hline TGX 1485-1D & 1.86 & 0.48 & 1.60 & 0.27 & 0.50 \\
\hline TGX 1835-10E & 1.83 & 0.18 & 0.86 & 0.34 & 0.58 \\
\hline TGX 1904-6F & 1.46 & 0.19 & 0.70 & 0.49 & 0.44 \\
\hline TGX 1951-3F & 1.85 & 0.19 & 0.95 & 0.84 & 0.54 \\
\hline TGX 1987-62F & 1.52 & 0.18 & 1.57 & 0.15 & 0.74 \\
\hline TGX 1989-19F & 1.45 & 0.15 & 0.86 & 0.75 & 0.58 \\
\hline TGX 923-2E & 1.09 & 0.10 & 0.66 & 0.55 & 0.50 \\
\hline TGX1987-10F & 1.68 & 0.54 & 1.23 & 0.08 & 0.27 \\
\hline $\mathrm{SE} \pm$ & 0.05 & 0.04 & 0.06 & 0.05 & 0.04 \\
\hline $\operatorname{LSD}(\mathrm{P}=0.05) \mathrm{SNK}$ & 0.10 & 0.09 & 0.13 & 0.099 & 0.09 \\
\hline
\end{tabular}


PROXIMATE AND MINERAL COMPOSITION OF SELECTED SOYBEAN GENOTYPES IN NIGERIA

\begin{tabular}{|c|c|c|c|c|c|c|c|c|}
\hline Genotype & $\begin{array}{c}\text { Dry matter } \\
(\%)\end{array}$ & $\begin{array}{c}\text { Moisture } \\
(\%)\end{array}$ & $\operatorname{Ash}(\%)$ & $\begin{array}{c}\text { Crude fat/oil } \\
(\%)\end{array}$ & $\begin{array}{c}\text { Crude } \\
\text { protein }(\%)\end{array}$ & $\begin{array}{c}\text { Crude fibre } \\
(\%)\end{array}$ & CHO (\%) & $\begin{array}{c}\text { Energy } \\
\text { value Kcal/g }\end{array}$ \\
\hline NG/AA/SEP/09/166 & 96.45 & 3.44 & 3.75 & 25.36 & 41.31 & 4.72 & 21.33 & 479.60 \\
\hline NG/MR/11/11/060 & 95.53 & 4.12 & 4.53 & 28.44 & 32.50 & 4.98 & 26.38 & 488.89 \\
\hline NG/SA/07/100 & 96.54 & 3.69 & 4.31 & 23.12 & 16.06 & 5.06 & 48.00 & 462.61 \\
\hline NG/SA/JAN/09/48 & 97.20 & 2.60 & 3.34 & 21.12 & 23.94 & 4.64 & 44.43 & 468.12 \\
\hline NGB 00111 & 95.30 & 4.74 & 5.12 & 27.65 & 20.48 & 5.11 & 36.63 & 479.39 \\
\hline NGB 00113 & 96.20 & 3.69 & 4.11 & 22.39 & 12.96 & 4.92 & 52.74 & 464.68 \\
\hline NGB 00116 & 96.42 & 3.66 & 5.36 & 26.93 & 41.92 & 5.32 & 15.83 & 477.17 \\
\hline NGB 01318 & 96.49 & 3.45 & 4.26 & 22.46 & 33.38 & 5.12 & 31.26 & 461.39 \\
\hline TGX 1019-2EB & 96.52 & 3.55 & 3.97 & 26.07 & 22.39 & 5.32 & 38.55 & 478.92 \\
\hline TGX 1019-2EN & 97.25 & 2.75 & 4.57 & 23.40 & 18.24 & 4.28 & 46.64 & 470.4 \\
\hline TGX 1440-1E & 95.25 & 4.75 & 4.12 & 24.30 & 32.56 & 6.09 & 28.57 & 459.97 \\
\hline TGX 1448-2E & 96.35 & 3.68 & 4.31 & 25.39 & 39.98 & 5.60 & 21.24 & 473.50 \\
\hline TGX 1485-1D & 96.62 & 3.82 & 4.11 & 23.54 & 27.31 & 5.11 & 36.40 & 468.93 \\
\hline TGX 1835-10E & 95.90 & 4.10 & 3.88 & 23.52 & 40.32 & 4.95 & 22.55 & 465.21 \\
\hline TGX 1904-6F & 96.42 & 3.62 & 4.19 & 28.11 & 36.30 & 4.18 & 23.54 & 484.44 \\
\hline TGX 1951-3F & 95.45 & 4.47 & 5.02 & 26.22 & 35.11 & 6.12 & 23.06 & 468.11 \\
\hline TGX 1987-62F & 98.34 & 1.88 & 5.11 & 25.15 & 31.43 & 5.12 & 31.50 & 476.04 \\
\hline TGX 1989-19F & 94.64 & 5.12 & 4.22 & 30.45 & 39.31 & 4.12 & 16.72 & 496.37 \\
\hline TGX 923-2E & 93.48 & 6.12 & 4.54 & 24.82 & 37.06 & 3.75 & 23.83 & 464.48 \\
\hline TGX1987-10F & 96.02 & 3.99 & 4.05 & 25.28 & 41.33 & 5.34 & 20.27 & 474.83 \\
\hline $\mathrm{SE} \pm$ & 0.57 & 0.24 & 0.29 & 0.60 & 0.56 & 0.32 & 0.48 & 6.33 \\
\hline $\begin{array}{l}\operatorname{LSD}(\mathrm{P}=0.05) \\
\text { SNK }\end{array}$ & 1.15 & 0.48 & 0.58 & 1.21 & 1.12 & 0.64 & 0.97 & 12.78 \\
\hline
\end{tabular}




\section{Discussion}

\section{Proximate composition of soybean genotypes}

The low moisture content observed in all the genotypes (Table 1), $1.88 \%$ in TGX1987-62F through 6.12\% in TGX923-2E shows these genotypes have less moisture due to more concentrates of other nutrients. This is an indication that all the genotype can be stored for a very long time since moisture which is an important medium for multiplication of microorganisms is very low in the genotypes. These results are in agreement with DAVIES (2008) who reported lower moisture content in full-fat soybeans. ETIOSA \& al. (2017) on the other hand reported higher moisture content in contrast to the findings of this experiment. The ash contents ranging from $3.34 \%$ to $5.02 \%$ for the genotypes under study is an indication that the genotypes could be important sources of minerals. SAULAWA \& al. (2014); SIULAPWA \& MWAMBUNGU (2014); EDEMA \& al. (2005) all reported higher ash contents, but reports of ranges of 1.01-1.67\% for ash content [ESHUN, 2012] was lower than those observed by the researchers. The high crude fat content observed in the genotypes NG/SA/JAN/09/48 (21.12\%) through TGX1989-19F (30.45\%) are in agreement with that reported by OGBEMUDIA \& al. (2017). These values however, were much higher than those reported by ADIE \& al. (2015). These authors had reported oil content range of 7.0-25\% for all 78 soybean varieties registered by Ministry of Agriculture Republic of Indonesia. LIU (2000) also reported that soybean seed had $18-21 \%$ oil. This suggests that the genotypes used for this study may be a viable source of higher oil quantity, going by their crude fat contents. And not just for Nigeria alone but beyond. Soybean crude fat is reported to have cholesterol reducing ability thereby making it essential oil for obese people diet. BALASUBRAMANIYAN \& PALANIAPPAN (2003) reported that the oil in soybean consists of $85 \%$ unsaturated fatty acid with two essential fatty acids (lenoleic and linolenic acid) which are not synthesized by the human body, thus highly desirable in human diet. Seeds from these exceptional genotypes could be used in weight-loss drinks, sport drinks, as low-fat substitute in hamburger, in commercial bakery industry to aid in dough conditioning and bleaching, as it possesses excellent moisture-holding qualities that help to retard staling in bakery products. Greater cultivation and consumption of these high oil containing genotypes will go a long way in improving diet and food security of the Nigerian populace.

The high protein content obtained in the following genotypes ranging from highest NGB 00116 TGX 1987-10F, NG/AA/SEP/09/166, TGX1835-10E, TGX1448-2E, TGX1989-19F are higher than the reported values $37.69 \%$ by SIULAPWA \& MWAMBUNGU (2014), 36.27\% by LIU (2000), $38.42 \%$ by STEIN \& al. (2008). The above genotypes are of nutritional importance to sub-Sahara Africa where protein energy malnutrition is a menace. They can be incorporated into diet formulations for weaning foods in infant and as an alternative to animal proteins which has problem low density lipoprotein that have adverse health effect such coronary diseases. Moreover, the health benefits of soy protein related to the reduction of cholesterol levels, menopause symptoms and reduction in risk for several chronic disease i.e., cancer, heart disease and osteoporosis have been reported [POTTER, 1998]. The genotypes with lower protein contents can be channeled into oil production and animal feed stock. The crude fibre of the genotypes ranging from $3.75 \%$ to $6.009 \%$ is relatively low as compared to OSMAN (2004) but similar to that of OKOYE \& al. (1980). The presence of fibre in foods is known to be beneficial. Fibre has some physiological effects in the gastrointestinal, tract. These effects include variation in fecal water, fecal bulk and transit time and elimination of bile acids and neutral steroids which lower the body 
cholesterol pool.The high carbohydrate contents of the genotypes suggests that the genotypes could be used in managing protein-energy malnutrition since there is enough quantity of carbohydrate to derive energy from in order to spare protein so that protein can be used for its primary function of building the body and repairing worn out tissues rather than as a source of energy. Genotypes having carbohydrates percentage above $25 \%$ are in agreement with the report of OGBEMUDIA \& al. (2017). This could be as result of the location or environment of cultivation and the type of nutrient supply in the course of production.

\section{Mineral concentrations soybean genotypes}

The minerals (calcium, potassium, sodium magnesium and phosphorus) contents of the genotypes are appreciably high, but they are consistent with the findings of OSMAN (2004) who found high level of these minerals. The above minerals are required in large quantity by humans thus processing is needed to be adopted in making them available for use. High calcium suggests that the genotypes could be used in complementary foods to help build the bones and teeth since calcium is one of the main components of teeth and bones. Calcium also plays a role in blood clotting. Magnesium is involved in making proteins and releasing energy and helps hold calcium in the enamel of the teeth. Phosphorus is closely linked with calcium. The two minerals combine to form calcium phosphate, which gives bones their rigid structure. Sodium is needed in the body in a small amount to help maintain normal blood pressure and normal function of muscles and nerves. Potassium helps in lipid metabolism and energy transduction in cellular membrane function [MEHAS \& RODGERS, 2012].Though it is a fact that mineral nutrients of plant origin are not readily available to man as a result of the inability to be absorbed in the small intestine, but complement those from animal origin [AGBAIRE \& EMOYAN, 2012].

\section{Conclusion and recommendations}

The studied genotypes have shown good nutritional qualities especially for protein and oil contents. The information contained in this paper will provide long needed bases for soybean quality improvement. The previously uncharacterized accessions NGB00116 and NG/AA/SEP/09/166 could be further evaluated by NACGRAB in collaboration with soybean breeding institutes for possible registration and release for exceptional quality of high protein content and NG/MR/11/11/060 for high oil content.

\section{Acknowledgement}

The authors are grateful for the supports received from Rural Development Administration (RDA), Republic of Korea through Korea-Africa Food and Agriculture Cooperative Initiative (KAFACI) funded project on Improvement of Technology on Conservation of Genetic Resources.

\section{Notes on contributors}

Dickson Junior NWOSU is a Plant Breeder/Geneticist with interest in crop improvement. His bias is towards legumes insect resistance and quality improvement. He is currently exploring cowpea wild relative as a genepool for genes of economic importance using morphological and molecular tools. $\mathrm{He}$ is also a biodiversity conservationist.

Mayowa Raphael OLUBIYI is a Plant Breeder and biodiversity conservationist. He is interested in genetic improvement of yield and quality of food security crops especially rice and soybean.

Sunday Ezekiel ALADELE is a Plant Breeder and biodiversity conservation expert. 
Benson APUYOR is a Biochemist with interest in post-harvest biology and food value addition for especially oil crops.

Anthony Ugochukwu OKERE is a Forest Biologist and Silviculturist with a special interest in improvement of indigenous timber, fruit trees, agronomic crops, medicinal plant species, forest biotechnology and biodiversity conservation.

Adetunji Ismael LAWAL research interests include post-harvest studies of agricultural crops, food processing and preservation, food products development and food processing engineering.

Gloria AFOLAYAN is a plant breeder and research scientist working on Sorghum improvement. She is also a conservationist.

Abisoye Oyepero OJO is an agronomist currently working on effects of rhizobial inoculation on genetic traits of soybean.

Myung-Chul LEE is interested in application of molecular biology tools in identification of promising crop cultivars especially rice and soybean.

Edna Chidinma NWOSU is a Biochemist with interest in crop improvement for human nutrition improvement.

\section{References}

*** ASSOCIATION OF ANALYTICAL CHEMISTS (A.O.A.C.). 2006. Official method of analysis. Washington DC.: 9-65.

ADIE M. M., KRISNAWATI A. \& HARNOWO D. 2015. Agronomic characteristic and nutrient content from several Soybean promising lines with high Isoflavones. Procedia Food Science. 3: 348-354.

AGBAIRE P. O. \& EMOYAN O. 2012. Nutritional and anti-nutritional levels of some local vegetables from Delta State. Nigeria. African Journal of Food Science. 6: 8-11.

AMEH G. I. 2007. Proximate and mineral composition of seed and tuber of African yam bean (Sphenostylis stenocarpa) (Hoechst. ex A. Rich.) Harms. Asset an International Journal Asset Series B. 6(1): 1-10.

BALASUBRAMANIYAN P. \& PALANIAPPAN S. P. 2003. Principles and practices of agronomy. Agrbios (India): 45-46. Chapter 1. Field crops. An overview.

DAVIES H. 2008. Processing of full-fat soybeans, proceedings of a workshop on the processing of full fat soybeans, Irene, South Africa: p. 21.

EDEMA M. O., SANNI L. \& SANNI A. I. 2005. Evaluation of maize-soybean flour blends for sour maize bread production in Nigeria. African Journal of Biotechnology. 4(9): 911-918.

ESHUN G. 2012. Nutrient composition and functional properties of bean flours of three soya bean varieties from Ghana. African Journal of Food Science and Technology. 3(8): 176-181.

ETIOSA R. O., CHIKA N. B. \& ANUGE B. 2017. Mineral and proximate composition of soya beans. Asia Journal of Physical and Chemical sciences. 4(3): 1-6.

GHOSH J., GHOSH P. D. \& CHOUDHURY P. 2014. An assessment of genetic relatedness between soybeans (Glycine max (L.) Merrill) cultivars using SSR markers. American Journal of Plant Sciences. 05: 3089-3096.

GUZMÁN-MALDONADO S. H., ACOSTA-GALLEGOS J. \& PAREDES-LÓPEZ O. 2000. Protein and mineral content of a novel collection of wild and weedy common bean (Phaseolus vulgaris L.). Journal of Science Food Agriculture. 80: 1874-1881.

HOSSAIN Z. \& KOMATSU S. 2014. Potentiality of soybean proteomics in untying the mechanism of flood and drought stress tolerance. Proteomes. 2(1): 107-127.

KUMAR A. V., KUMAR S., LAL K., JOLLY M. \& SACHDEV A. 2014. Influence of gamma rays and ethylmethanesulphonate (EMS) on the levels of phytic acid, raffinose family oligosaccharides and antioxidants in soybean seeds of different genotypes. Journal of Plant Biochemistry and Biotechnology. 24: 204-209.

LEHNER U. \& GAWRISCH W. 2000. Sustainability means future viability. Henkel Sustainability Report 2000: 40 pp.

LIU K. 2000. Expanding soybean food utilization. Journal of Food Technology. 54(7): 46-58.

ODELEYE F. O., ODELEYE O. M. O. \& ANIMSHAUN M. O. 2007. Effects of nutrient foliar spray on soybean growth and yield (Glycine $\max$ (L.) Merrill.) in south west Nigeria. Notulae Botanicae Horti Agrobotanici Cluj-Napoca. 35(2): 22-32.

OSMAN M. 2004. Chemical and nutrient analysis of Baobab (Adansonia digitata) fruit and seed protein solubility. Plant Food Human and Nutrition. 59: 29-33. 
MALEK M. A., RAFFI M. Y., AFROJ M. S. S., NATH U. K. \& MONDOL M. M. A. 2014. Morphological characterization and assessment of genetic variability, character association, and divergence in soybean mutants. The Scientific World Journal. 1-12.

MEHAS K. Y. \& RODGERS S. L. 2012. Food science. The Biochemistry of Food and Nutrition. $3^{\text {rd }}$ Edition. Glencoe / McGraw-Hill, Peoria Illinois, U.S.A. 35: 169-171.

NWADIKE C., OKERE A., NWOSU D., OKOYE C., VANGE T. \& APUYOR B. 2018. Proximate and nutritional composition of some common bean (Phaseolus vulgaris L.) and cowpea (Vigna unguiculata L. Walp) accessions of Jos-Plateau, Nigeria. Journal of Agriculture and Ecology Research International. 15(1): 1-9.

OGBEMUDIA R. E., NNADOZIE B. C. \& ANUGE B. 2017. Mineral and proximate composition of soya bean. Asian Journal of Physical and Chemical Sciences. 4(3): 1-6.

OKOYE W. I., KAZAURE I. \& EGESI G. V. 1980. A preliminary investigation of Baobab (Adansonia digitata L.) as a potential source of oilseed. Annual Report of Nigerian Stored Products Research Institute, 1977 1978: 73-75.

POTTER S. M. 1998. Soy protein and cardiovascular disease: the impact of bioactive component in soy. Nutrition Review. 56: 231.

SADZAWKA A., CARRASCO M. A., DEMANET R., FlORES H., GREZ R., MORA M. L. \& NEAMAN Y. A. 2007. Métodosde análisis de tejidos vegetales. $2^{\mathrm{a}}$ ed. Serie Actas INIA No 40.140 Instituto de Investigaciones Agropecuarias. Santiago, Chile: 53-59.

SATHE S. K., SHARMA G. M., KSHIRSAGAR H. H., SU M. \& ROUX K. H. 2009. Effects of long-term frozen storage on electrophoretic patterns, immune reactivity, and pepsin in vitro digestibility of soybean (Glycine max L.) proteins. Journal of Agricultural and Food Chemistry. 57: 1312-1318.

SAULAWA L. A., YARADU A. I. \& SHUAIBU L. 2014. Effect of different processing methods on proximate, mineral and anti-nutritional factors content of baobab (Adansonia digitata) seeds. Pakistan Journal of Nutrition. 13(6): 314-318.

SHARMA S., KAUR M., GOYAL R. \& GILL B. S. 2013. Physical characteristics and nutritional composition of some new soybean (Glycine max (L.) Merrill) genotypes. Journal of Food Science and Technology. 51: 551-557.

SIULAPWA N. \& MWANBUNGU A. 2014. Nutritional value of differently processed soybean seeds. International Journal of Research in Agriculture and Food Sciences. 2(6): 8-16.

SMITH R. E., SCHUTZ R. W., SMOLL F. L. \& PTACEK J. 1995. Development and validation of a multidimensional measure of sport-specific psychological skills: The athletic coping skills inventory 28. Journal of Sport and Exercise Psychology. 17(4): 379-398.

STEIN H. H., BERGER L. L., DRACKLEY J. K., FAHEY G., HERNOT D. C. \& PARSONS C. 2008. Nutritional properties and feeding values of soybeans and their co-products: 613-630. In: LAWRENCE A. J., WHILEP. J. \& GALLOWAY R. (Eds.) Soybeans, chemistry, production, processing and utilization, AOCS Publishing.

\section{How to cite this article:}

NWOSU D. J., OLUBIYI M. R., ALADELE S. E., APUYOR B., OKERE A. U., LAWAL A. I., AFOLAYAN G., OJO A. O., NWADIKE C., LEE M. C. \& NWOSU E. C. 2019. Proximate and mineral composition of selected soybean genotypes in Nigeria. J. Plant Develop. 26: 67-76. https://doi.org/10.33628/jpd.2019.26.1.67 